удк 378. 316.613

Світлана Калаур

Тернопільський національний педагогічний

університет імені Володимира Гнатюка

ORCID ID 0000-0001-8099-9392

Ольга Сорока

Тернопільський національний педагогічний

університет імені Володимира Гнатюка

ORCID ID 0000-0003-1483-8974

DOI 10.24139/2312-5993/2019.08/229-238

\title{
МЕТОДОЛОГІЧНІ ТА ПРАКТИЧНІ АСПЕКТИ ВПРОВАДЖЕННЯ СИСТЕМНОГО ПІДХОДУ У ПРОФЕСІЙНУ ПІДГОТОВКУ МАЙБУТНІХ МЕНЕДЖЕРІВ СОЦІОКУЛЬТУРНОї ДІЯЛЬНОСТІ
}

У статті акцентовано увагу на потенціалі системного підходу у профресійній підготовці майбутніх менеджерів соціокультурної діяльності. Доведено, що цей підхід допоможе організувати підготовку студентів як цілісну систему, що передбачає єдність психолого-педагогічної теорії, методології та практики. На основі системного підходу здійснювався осмислений пошук ефективних шляхів організації освітнього процесу студентів спеціальності 028 Менеджмент соціокультурної діяльності. Основна мета його застосування полягала у формуванні в майбутніх фахівців практичних умінь компетентно вирішувати широкий спектр професійних завдань. У практичному контексті висвітлено системність у вивченні трьох навчальних дисциплін з циклу професійної та практичної підготовки.

Ключові слова: системний підхід, заклад вищої освіти, майбутні менеджери соціокультурної діяльності, професійна підготовка, навчальні дисципліни, цикл професійної та практичної підготовки.

Постановка проблеми. Поділяємо позицію О. Венгловської, Л. Кузьменко та І. Новик про те, що «реформування системи освіти в Україні висуває кардинально нові вимоги до особистісно-професійного розвитку майбутніх фахівців» (Венгеловська, 2019, с. 3). Зокрема, нині відчувається конкретна потреба в суттєвій зміні ринку освітніх послуг, яка пов'язана з тим, що певні спеціальності втратили актуальність та привабливість на сучасному ринку праці, а інші, навпаки, лише з'явилися на «професійній орбіті» нашої держави. Саме до таких нових і перспективних спеціальностей належить «Менеджмент соціокультурної діяльності». У Тернопільському національному педагогічному університеті імені Володимира Гнатюка лише у 2018 році розпочалася професійна підготовка бакалаврів за спеціальністю 028 Менеджмент соціокультурної діяльності.

Спеціальність менеджмент соціокультурної діяльності виникла на стику педагогіки, культурології, соціології, психології, технології, економіки й управління соціально-культурною сферою. Як доводить Н. Кочубей, 
менеджмент соціокультурної діяльності $€$ системою дій, що відображає цілі й функції державної політики в галузі культури і дозвілля, визначає шляхи, методи та засоби їх реалізації; являє собою керований суспільством і його соціальними інститутами процес залучення людини до культури й активного включення самої людини в цей процес (Кочубей, 2015). Тобто, у найбільш загальному контексті майбутній фахівець соціально-культурної сфери має бути готовий до самовдосконалення під час організації дозвіллєвої діяльності та повинен узяти на себе місію виховання активного, ініціативного, самостійного громадянина, освіченої, культурної людини.

Аналіз актуальних досліджень. Сучасна соціокультурна ситуація в Україні характеризується низкою негативних тенденцій, які суттєво вплинули на певне знецінення духовно-моральних і культурних орієнтирів та спричинило «відчуження» від культури й мистецтва. Поділяємо позицію В. Бочелюк (Бочелюк, 206) щодо того, що в Україні давно назріла потреба в активному оновленні й активізації сфери дозвілля, тому відбувається складний процес інноваційних змін і пошук нових підходів у цьому напрямі. Криза системи організації дозвілля та відпочинку потребує системних змін у професійній підготовці фахівці, які будуть організовувати. Тобто нині рівень організації дозвілля не відповідає сучасним потребам українського соціуму, тому потребує суттєвого вдосконалення. У цьому контексті сучасний етап розвитку ЗВО потребує пошуку новітніх технологій професійної підготовки майбутніх фахівців до дозвіллєвої діяльності.

Професійна підготовка майбутніх фахівців у ЗВО розглядається в якості каталізатора соціальної мобільності, що забезпечує розвиток кваліфікованого фахівця. У Концепції розвитку освіти України на період 2015-2025 р.р. наголошено на необхідності системної реформи, яка має утвердити розуміння того, що освіта нині $є$ вагомим важелем цивілізаційного поступу й економічного розвитку нашої країни. На наш погляд, якісний освітній процес для студентів, які готуються стати організаторами соціокультурної діяльності, неможливий без використання системного підходу.

Беручи до уваги наведені вище аргументи, ми поставили собі за мету розкрити потенціал системного підходу під час професійної підготовки майбутніх менеджерів соціокультурної діяльності, а також розкрити методичні та практичні площини його впровадження в освітній процес Тернопільського національного педагогічного університету імені Володимира Гнатюка.

Методи дослідження. Для досягнення поставленої мети використовувалися відповідні авторському задуму методи дослідження: аналіз нормативних документів, філософських, соціологічних, психологічних і педагогічних праць із метою обгрунтування потенціалу системного підходу у професійній підготовці майбутніх менеджерів соціокультурної діяльності; систематизація теоретичних положень, а також узагальнення й корекція теоретико-методичних позицій для наукового обґрунтування практичних 
шляхів професійної підготовки студентів спеціальності 028 Менеджмент соціокультурної діяльності під час навчання.

Виклад основного матеріалу. Насамперед відзначимо, що 3 методологічної позиції професійну підготовку майбутніх фахівців у 3 ВО доцільно розглядати як специфічний соціокультурний інститут, через який здійснюється трансляція спеціалізованого соціального та культурного досвіду, накопиченого суспільством. Тобто в загальнонауковому контексті професійна підготовка передбачає використання двох стратегій «по-перше, освіту як процес і результат оволодіння певним стандартизованим змістом освіти у формі знань, умінь, навичок, компетентностей і компетенцій; подруге, освіту як безперервний процес розвитку, становлення особистості, що передбачає формування мотиваційної сфери, пізнавальних здібностей, соціально і професійно важливих якостей» (Калаур, 2017, с. 116).

Навчаючись у 3ВО, майбутній фахівець соціокультурної діяльності не просто реалізує себе, роблячи вибір між репродуктивним способом професійної діяльності й творчістю, він має змогу якісно змінити й удосконалити себе, переосмислити свої професійні очікування, віднайти реальні можливості для творчого розвитку професійно-значущих якостей, виробити власну концепцію реалізації професійних функцій. У цілому, для творчої професійної діяльності фахівця соціокультурної сфери характерні, по-перше, інноваційна спрямованість, по-друге, скерованість на розвиток себе як індивідуальності в процесі творчої діяльності. Фахівець під час професійної підготовки має чітко усвідомити, що без самовдосконалення, саморозвитку неможливе зростання у професійній сфері.

Під час професійної підготовки майбутніх фахівців вагому роль відіграють правильно підібрані методологічні підходи. Так, В. Галузинський та М. Євтух (Галузинський, 1995) вважають, що підходи, з психологопедагогічної точки зору, виступають у якості комплексних і взаємопов'язаних впливів на студентів, що допомагають формувати професійно успішну особистість. У баченні І. Зімньої, підходи розглядаються як «світоглядна категорія, що повинна охопити методи, форми, прийоми організації освітнього процесу» (Зімняя, 2002, с. 97). Таким чином, саме через підходи, як світоглядну категорію, відображаються соціальні настанови, які орієнтують викладацький склад 3 ВО на реалізацію освітньої діяльності майбутніх менеджерів соціокультурної діяльності. У нашому розумінні наукова дефініція «підхід» відображає концептуальні засади організації освіти, $€$ носієм узагальненої інформації у професійній підготовці, що дозволяє якісно та різнобічно охопити найбільш адекватні методи, форми, прийоми та засоби практичної діяльності, які доцільно використовувати в освітньому процесі організації освітнього процесу під час формування у студентів готовності до професійної діяльності. Вважаємо, що серед усього спектру методологічних підходів провідну роль посідає системний підхід. 
Роблячи акцент на системному підході, за основу були враховані погляди В. Семиченко стосовно того, що цей підхід допоможе нам «розглядати комплексні, складні об'єкти в динаміці їх виникнення й передбачати потенційні зміни» (Семиченко, 2004, с. 255). Ми також прийняли до уваги думку О. Дахіна про те, що сутність системного підходу полягає в тому, що на основі екстенсивного розширення системи вводяться додаткові підмоделі, які враховують різноманітні фактори й напрями в динаміці дослідження (Дахін, 2009, с. 100). Поділяємо позицію В.Докучаєвої про те, що саме системний підхід допоможе зорієнтувати професійну підготовку майбутніх фахівців як цілісну систему, що передбачає єдність психолого-педагогічної теорії, методології та практики (Докучаєва, 2007). Таким чином, цей підхід $є$ гуманістичним, оскільки створює оптимальні умови для розвитку особистості майбутнього професіонала, сприяє самопізнанню й самоствердженню та спрямований на актуалізацію професійно-особистісного потенціалу.

Узагальнюючи погляди науковців, вважаємо, що в контексті системного підходу професійна підготовка майбутніх фахівців, які здійснюватимуть соціокультурну діяльність, має передбачати такі складові, як:

1) ґрунтовну теорію, яка дає основу для поглиблення когнітивної складової готовності до професійної діяльності;

2) методологію, яка слугуватиме концептуальною основою;

3) практичну підготовку, яка виступатиме вагомим чинником формування практичних умінь й навичок організації соціокультурної діяльності й дозволяє перевірити дієвість фундаментальних теорії та методології.

У нашому розумінні системний підхід допомагає здійснити осмислений пошук ефективних шляхів організації освітнього процесу у стінах 3ВО. 3 цієї точки зору, основна мета застосування системного підходу полягає у формуванні в майбутніх фахівців практичних умінь компетентно вирішувати широкий спектр практико орієнтованих завдань. Зокрема, у процесі професійної підготовки у ЗВО майбутні менеджери соціокультурної діяльності мають навчитися реалізовувати таки види діяльності, як:

а) творчо-виробничу (розробка культурних програм і соціальнокультурних заходів, спрямованих на творчий розвиток дітей, молоді і дорослих, організацію дозвілля населення);

б) організаційно-управлінську (здійснення менеджменту й маркетингу у сфері соціокультурної діяльності, здійснення керівництва закладами культури);

в) художнє керівництво діяльністю закладів культури (визначення мети і пріоритетних напрямів творчо-виробничої діяльності закладів культури, що реалізують соціокультурні технології (культурно-просвітницькі, культурноохоронні, культурно-дозвіллєві, рекреаційні тощо));

г) науково-методичну (науково-методичне та інформаційне забезпечення соціокультурної діяльності, надання інформаційних і 
методичних послуг, а також поширення інноваційного досвіду діяльності закладів соціокультурної сфери в контексті реалізації завдань державної культурної політики, соціального і культурного виховання громадян);

д) проектну (участь у розробці й обґрунтуванні соціокультурних проектів та програм);

е) педагогічну та соціально-виховну (проведення теоретичних i практичних занять із навчальних дисциплін соціокультурної діяльності в закладах загальної середньої освіти та установах позашкільної освіти, закладах перепідготовки й підвищення кваліфікації у сфері культури і мистецтва, закладах соціально-педагогічного спрямування).

у практичному аспекті системний підхід під час організації професійної підготовки майбутніх менеджерів соціокультурної діяльності на базі кафедри соціальної педагогіки і соціальної роботи Тернопільського національного педагогічного університету імені Володимира Гнатюка було реалізовано в такій послідовності:

1) системне проектування розвивального освітнього середовища;

2) оновлення змісту професійної підготовки на основі запровадження інноваційний освітніх технологій;

3) формування професійних здібностей, які забезпечують підтримку висхідного поступального професійного розвитку;

4) розвиток у студентів внутрішньої спрямованості на особистісний і професійний розвиток;

5) цілеспрямований аналіз результатів, яких досягають студенти, та внесення коректив у їхню пізнавальну діяльність.

У методологічній площині, на основі порад В. Ягупова (Ягупов, 2003), було виокремлено конкретні правила, яких дотримувалися викладачі кафедри соціальної педагогіки і соціальної роботи Тернопільського національного педагогічного університету імені Володимира Гнатюка, впроваджуючи системний підхід у професійну підготовку студентів спеціальності «Менеджмент соціокультурної діяльності, а саме:

- логічне структурування змісту теоретичного матеріалу та його послідовний розподіл;

- чітке виокремлення головного в навчальному матеріалі;

- перехід від простих форм і засобів організації освітнього процесу до більш складних;

- логічне врахування особливостей майбутньої професійної діяльності під час вивчення теоретичного матеріалу 3 професійно орієнтованих дисциплін.

Насамперед акцентуємо увагу на тому, що викладацьким складом кафедри було заплановано системне та поступове занурення майбутніх менеджерів соціокультурної діяльності в теоретичні, методичні та практичні аспекти майбутньої професії. Так, для студентів, які здобувають освіту в галузі 
знань 02 Культура і мистецтво, спеціальності 028 Менеджмент соціокультурної діяльності було запропоновано конкретні навчальні предмети з циклу професійної та практичної підготовки («Вступ до спеціальності», «Теорія соціокультурної діяльності» та «Менеджмент соціокультурної діяльності»), які відповідають усім окресленим вище вимогам.

Зокрема, для початкового опанування фаховою компетентністю та «занурення» в майбутню професію в навчальному плані професійної підготовки майбутніх менеджерів соціокультурної діяльності на першому курсі читається перша професійно орієнтована навчальна дисципліна «Вступ до спеціальності» (1 семестр, 4 кредити). Мета викладання цієї навчальної дисципліни полягає в орієнтуванні студентів щодо: змісту соціокультурної діяльності, її об'єктивної зумовленості та ролі в сучасному суспільстві України; функцій, принципів, історико-культурних та морально-етичних, організаційних засад соціокультурної діяльності; категоріального апарату спеціальності; формування знань, умінь і навичок менеджера соціокультурної діяльності як основи організації функціонування установ соціокультурної сфери; професійної етики менеджера соціокультурної діяльності. До головних завдань, на яких була зосереджена увага віднесено: вивчення сучасного становища та перспектив розвитку спеціальності в Україні; ознайомлення зі сферами професійної діяльності фахівця соціокультурної діяльності; розкриття основних положень соціокультурної діяльності; формування емоційно-позитивного ставлення студентів до подальшої професійної діяльності; усвідомлення важливості етичних принципів та норм у соціально-культурної діяльності, необхідності оволодіння професійно-етичними якостями майбутніми фахівцями соціокультурної сфери. У контексті задекларованої мети та завдань студенти мали змогу опанувати два змістових модуля («Загальні теоретичні засади соціокультурної діяльності», «Практичні засади організації соціокультурної діяльності»).

Для більш ґрунтовного й системного опанування методичними аспектами організації соціокультурної діяльності на другому році навчання студенти мають змогу опанувати навчальну дисципліну «Теорія соціокультурної діяльності» (3 семестр, 5 кредитів), яка мала на меті ознайомлення студентів із ґенезою соціально-культурної діяльності як особливої галузі людської діяльності, формування базових знань і ціннісних орієнтацій у соціокультурній сфері. Основними завданнями вивчення дисципліни $\epsilon$ : аналіз сучасних тенденцій соціокультурного розвитку; формування стійкого уявлення про специфіку соціокультурної діяльності; вивчення теоретичних основ соціокультурної діяльності. Так, вивчаючи цю дисципліну студенти аналізують особливості становлення соціокультурної діяльності в Україні, вивчають актуальність соціокультурної діяльності в Україні, досліджують пріоритетні напрями діяльності фахівців соціокультурної сфери та інфраструктуру соціокультурної діяльності, мають 
змогу опанувати професійними функціями фахівців соціокультурної сфери та ознайомитися зі складовими їхньої професійної компетентності. Загалом студентам пропонується опанувати двома змістовими модулями: «Теорія соціокультурної діяльності в системі науково-практичного знання» та «Сутнісні характеристики соціокультурної діяльності».

На третьому курсі майбутні фахівці вивчають професійно орієнтований курс «Менеджмент соціокультурної діяльності» (6 семестр, 5 кредитів), який має міждисциплінарні зв'язки з такими навчальними дисциплінами, як «Теоретичні і прикладні засади менеджменту»; «Івент-менеджмент»; «Основи PR». Метою викладання навчальної дисципліни «Менеджмент соціокультурної діяльності» $\epsilon$ формування у студентів сучасного управлінського мислення та системи спеціальних знань у галузі менеджменту соціокультурної сфери, формування розуміння основ системного управління організаціями, набуття умінь аналізу внутрішнього та зовнішнього середовища, прийняття адекватних управлінських рішень. Тобто, у методологічному аспекті навчальна дисципліна «Менеджмент соціокультурної діяльності» спрямована на формування в майбутніх фахівців сучасного управлінського мислення та розвиток цілісної системи спеціальних практичних умінь у галузі менеджменту соціокультурної діяльності та розуміння основ системного управління культурно-дозвіллєвими організаціями, набуття умінь прийняття адекватних управлінських рішень у соціокультурній діяльності. Наголосимо на тому, що на сучасному етапі розвитку соціокультурної сфери в нашій країні основні завдання майбутнього фахівця, який хоче ефективно працювати на ринку надання соціокультурних послуг $€$ всебічне вивчення ринку попиту. Тобто, навчальна дисципліна «Менеджмент соціокультурної діяльності» не лише в методичному, а й у практичному контексті спрямована на якісне вдосконалення управління соціокультурною сферою. Це особливо актуально на сучасному етапі, оскільки постійно зростає кількість організацій, що діють у соціокультурній галузі, збільшується мережа платних культурно-дозвіллєвих послуг.

Таким чином, використовуючи системний підхід, було здійснено комплексне поєднання навчальних дисциплін («Вступ до спеціальності», «Теорія соціокультурної діяльності» та «Менеджмент соціокультурної діяльності»), що дозволило уникнути повторів і дубляжів теоретичного матеріалу, наповнити навчальні курси конкретним професійним змістом, а також логічно пов'язати предмети між собою. Усе це, як показав наш викладацький досвід, забезпечимо цілісність професійної підготовки та мало позитивний вплив на формування професіоналізму майбутніх менеджерів соціокультурної діяльності.

Підсумовуючи, акцентуємо увагу на тому, що фахівець соціокультурної діяльності має великий вибір на ринку професій: соціальні інститути духовного виробництва; освітньо-виховні установи; науково- 
просвітницькі установи; заклади охорони та зберігання культурних цінностей; засоби поширення культури; культурно-дозвіллєві установи; відомчі культурно-освітні установи; санаторно-курортні і спортивнооздоровчі установи; туристсько-екскурсійні установи; розважальнокомерційні установи; реклама. Окрім цього, майбутні фахівці можуть працювати PR-менеджерами артистів, прес-секретарями, помічниками продюсерів, адміністраторами тощо.

Висновки та перспективи подальших наукових розвідок. Майбутні бакалаври під час навчання у ЗВО мають активно формувати власний громадянський і професійний статус та активно готуватися до реалізації соціокультурної творчості, ефективної організації дозвілля, рекреації й туризму, а також до проведення соціально-виховної та культурної діяльності й освіти. У найбільш загальному контексті цілями навчання студентів спеціальності 028 Менеджмент соціокультурної діяльності у ЗВО $\epsilon$ формування й розвиток загальних та професійних компетентностей у галузі соціокультурної діяльності та управління діяльністю закладів соціокультурної сфери. Беручи до уваги наведені аргументи, вважаємо за необхідне під час професійної підготовки ефективно використовувати системний підхід. У нашому баченні впровадження системного підходу, насамперед, пов'язане з нагальною необхідністю внесення кардинальних змін у їі пріоритетні орієнтири, що в практичному сенсі передбачає подолання формалізму в засвоєнні знань та виробленні самостійності в пізнавальній діяльності студентів спеціальності менеджмент соціокультурної діяльності.

Подальші дослідження будуть спрямовані на вивчення потенціалу праксеологічного та акмеологічного підходів у професійній підготовці майбутніх менеджерів соціокультурної діяльності, а також використання інноваційних освітніх технологій.

\section{ЛITEPATУPA}

Бочелюк, В. Й. Бочелюк, В.В. (2006). Дозвіллєзнавство. К.: Центр навчальної літератури (Bocheliuk, V. Ye., Bocheliuk, V. V. (2006). Leisure Studies. K.: Center for Educational Literature).

Венгловська, О., Куземко, Л., Новик, І. (2019). Використання інtернет-ресурсів в особистісно-професійному розвитку майбутніх педагогів. Педагогічні науки: теорія, історія, інновачійні технології, 4 (88), 3-17 (Venhlovska, O., Kuzemko, L., Novyk, I. (2019). Using internet resources in future teachers' personal and professional development. Pedagogical sciences: theory, history, innovative technologies, 4 (88), 3-17).

Галузинський, В. Г., Євтух, М.Б. (1995). Основи педагогіки та психології вищої школи. К.: ІНТЕЛ (Galuzinsky, V. G., Yevtukh, M. В. (1995). Fundamentals of higher education pedagogy and psychology. K.: INTELL).

Дахин, А.Н. (2009). Моделирование компетентности участников открытого образования. M. (Dakhin, A. N. (2009). Modeling the competence of participants in open education. M.). 
Докучаєва, В. В. (2007). Теоретико-методологічні засади проектування інноваційних педагогічних систем (дис. ... докт. пед. наук: 13.00.01). Луганськ (Dokuchaieva, V. V. (2007). Theoretical and methodological foundations of designing innovative pedagogical systems (DSc thesis abstract). Lugansk).

Зимняя, И. А. (2002). Педагогическая психология. М. (Zimniaia, I. A. (2002). Educational Psychology: a textbook for universities. M.).

Калаур, С. М. (2017). Філософсько-методологічні засади організації освітньої підготовки майбутній фахівців соціономічних професій. Науковий вісник Ужгородського університету. Серія: «Педагогіка. Соціальна робота», 2 (41), 115-118 (Kalaur, S. M. (2017). Philosophical and methodological principles of organization of educational preparation for future specialists of socio-economic professions. Uzhgorod University Scientific Bulletin. Series: "Pedagogy. Social Work", 2 (41), 115-118).

Кочубей, Н.В. (2015). Соціокультурна діяльність. Суми: Університетська книга (Kochubei, N. V. (2015). Socio-cultural activity. Sumy: University Book).

Семиченко, В.А. (2004). Психологія педагогічної діяльності. К.: Вища школа (Semichenko, V. A (2004). Psychology of pedagogical activity. K.: Higher School). Ягупов, В. В. (2003). Педагогіка. К. (Yagupov, V. V. (2003). Pedagogy. K.).

\section{PEЗЮME}

Калаур Светлана, Сорока Ольга. Методологические и практические аспекты внедрения системного подхода в профессиональной подготовке будущих менеджеров социокультурной деятельности.

В статье акцентировано внимание на потенциале системного подхода в профрессиональной подготовке будущих менеджеров социокультурной деятельности. Доказано, что этот подход поможет организовать подготовку студентов как целостную систему, предполагает единство психолого-педагогической теории, методологии и практики. На основе системного подхода осуществлялся осмысленный поиск эрфрективных путей организации образовательного процесса студентов специальности 028 Менеджмент социокультурной деятельности. Основная цель его применения заключалась в формировании у будущих специалистов практических умений компетентно решать широкий спектр профессиональных задач. В практическом контексте освещены системность в изучении трех учебных дисциплин из цикла профессиональной и практической подготовки.

Ключевые слова: системный подход, учреждение высшего образования, будущие менеджеры социокультурной деятельности, профрессиональная подготовка, дисциплины, цикл профессиональной и практической подготовки.

\section{SUM MARY}

Kalaur Svitlana, Soroka Olga. Methodological and practical aspects of a systems approach implementation in professional training of future managers of socio-cultural activities.

The article focuses on the potential of a systems approach in professional training of future managers of socio-cultural activities. It is considered in the study that the systems approach is a leading factor that provides actualization of students' professional and personal potential. The main purpose of the systems approach is to develop skills for the future to be able to competently solve a wide range of practically oriented tasks. In the context of the systems approach, training of future professionals who will carry out socio-cultural activities should include such components as: 1) a grounded theory that provides the basis for deepening the cognitive component of readiness for professional activity; 2) a methodology that will serve as a 
conceptual framework; 3) practical training, which will be a significant factor in the formation of practical abilities and skills of socio-cultural activities organization.

On the basis of the systems approach, a meaningful search for effective ways of the educational process organization for students of the specialty $028 \mathrm{M}$ anagement of socio-cultural activity has been conducted. The practical sequence of the systems approach implementation is analyzed. It includes: systematic design of the developmental educational environment; updating the content of vocational training based on the innovative educational technologies introduction; formation of professional abilities and development of internal orientation for personal and professional development; purposeful analysis of the results achieved by the students and making adjustments to their cognitive activities. The article also outlines the main rules that we adhered to while implementing the systems approach to the Ternopil national Volodymyr Hnatyuk pedagogical university educational process.

Using a systems approach, a complex combination of disciplines "Introduction to the specialty", "Theory of socio-cultural activity" and "Management of socio-cultural activity" was conducted. From a practical point of view, this made it possible to avoid repetition and duplication of theoretical material, to complete training courses with specific professional content. As well as to logically combine the subjects with each other. All this had a positive impact on the future socio-cultural activities managers' professionalism formation.

Key words systems approach, higher education institution, future managers of sociocultural activities, vocational training, educational disciplines, cycle of vocational and practical training.

UDC 378.147:37.091.113]:[001.895:008]:378.22

Dmytro Kozlov

Sumy State Pedagogical University named after A. S. Makarenko

ORCID ID 0000-0003-1875-0726

DOI 10.24139/2312-5993/2019.08/238-247

\section{MAJOR CHARACTERISTICS OF INNOVATIVE CULTURE OF THE FUTURE MANAGER OF THE SECONDARY EDUCATION INSTITUTION}

The article deals with the concepts: innovation, innovative culture of the future manager of the secondary education institution; historical analysis of their interaction in the field of education is conducted. The essence of development of innovative culture of the future manager of the secondary education institution and its main characteristics are described in the article, the conditions that influence the success of the professional activity of the future manager of the secondary education institution are described. The concepts of "innovative culture of society" and "innovative culture of personality" are considered in terms of scientific approaches. Characteristic features of managerial approaches to formation of innovative culture are defined. Particular attention is paid to human capital in the modern society and development of high culture between the participants of economic relations. The main tasks of the innovative culture of the future manager of the secondary education institution are formed and defined.

Key words innovation, innovative culture, innovation processes, future manager of the education institution. 